Grand Valley State University

ScholarWorks@GVSU

Winter 1999

\title{
Resource Consultation Model in Gifted Education to Support Talent Development in Today's Inclusive Schools
}

\author{
Robert J. Kirschenbaum \\ Clover Park School District \\ Dorothy Ciner Armstrong \\ Grand Valley State University, armstrod@gvsu.edu \\ Mary S. Landrum \\ Kent State University
}

Follow this and additional works at: https://scholarworks.gvsu.edu/coe_articles

Part of the Education Commons

\section{ScholarWorks Citation}

Kirschenbaum, Robert J.; Ciner Armstrong, Dorothy; and Landrum, Mary S., "Resource Consultation Model in Gifted Education to Support Talent Development in Today's Inclusive Schools" (1999). Peer Reviewed Articles. 10.

https://scholarworks.gvsu.edu/coe_articles/10

This Article is brought to you for free and open access by the Education at ScholarWorks@GVSU. It has been accepted for inclusion in Peer Reviewed Articles by an authorized administrator of ScholarWorks@GVSU. For more information, please contact scholarworks@gvsu.edu. 


\section{Resource Consultation Model in Gifted Education to Support Talent Development in Today's Inclusive Schools}

\author{
Robert J. Kirschenbaum \\ Glover Park School District \\ Tacoma, WA
}

\author{
Dorothy Ciner Armstrong \\ Grand Valley State University
}

\author{
Mary S. Landrum \\ Kent State University
}

\begin{abstract}
This article discusses the advantages and challenges that educators of gifted, talented, and creative students may encounter when taking on the new role of classroom consultant rather than, as they have typically done previously, directly providing programming and services to the students themselves. A discussion of the use of the consultation model within a gifted education program concludes the article.
\end{abstract}

Support for gifted education has waxed and waned over the years, and the current trend is to avoid segregating students in special programs outside the regular classroom (Renzulli \& Reis, 1991). Therefore, efforts must be made to provide enrichment program options for gifted, talented, and creative students within an inclusionary general education model. An essential ingredient in the implementation of this approach to gifted education is the development and acceptance of a consultation model (Robinson \& Ringlaben, 1992). This "integrated" gifted education model changes the role of teacher of the gifted from that of working directly with gifted students to being a consultant who can provide regular education teachers with direct and indirect services in the areas of identification, curriculum modification, and assessment.

There is typically little collaboration between regular education teachers and gifted education teachers (Parke, 1989). Gifted education teachers or specialists usually offer a curriculum that is separate and distinct from what is presented to students in regular classes. As schools move toward serving students with exceptional learning needs within the regular classroom, not outside of it, classroom teachers must provide appropriate differentiation for their own gifted, talented students (Renzulli, 1994). Regular education teachers, however, report making very few efforts to modify their curriculum for gifted learners (Archambault et al., 1993).
Direct observations corroborate that there is little differentiation in the instructional and curricular practices, grouping arrangements, and verbal interactions for gifted and talented students in the regular classroom when compared to matched controls in the same classrooms (Westberg, Archambault, Dobyns, \& Salvin, 1993). The effectiveness of classroom teachers in meeting the educational needs of gifted, talented, and creative students is further challenged by such impediments as large class size, competing demands for teacher time, and the lack of teacher preparation in the curricular approaches that are appropriate for them (Tomlinson, 1994/1995). Westberg, Archambault, Dobyns, and Salvin concluded that informing teachers about what they should be doing is not as effective as showing them how to implement modified curricular activities. They recommended that the gifted education specialist needs to take responsibility for providing

\section{PUTTING THE RESEARCH TO USE}

Several major initiatives in the educational reform movement have had a negative impact on the education of gifted children across the country. The abolishment of ability grouping, the development of the middle school model, and inclusion of all have led to decreases if not total abandonment of the traditional gifted education program. The gifted education field must respond proactively to these changes by rethinking the format of gifted education services so that we complement rather than conflict with current educational forces in general education. The resource consultation model does so. Whether schools adopt an entire consultative approach or just restructure their gifted education programming to be more consultative and collaborative with general education, the result will be a more integrated and thriving coordination of services for gifted learners. This article provides a description of such efforts. 
assistance (i.e., consultative assistance) to the classroom teacher for meeting the needs of highly able students. The purpose of this article is to discuss the possibilities, promises, and problems associated with the use of resource consultation and collaboration where services are primarily delivered by regular classroom teachers.

\section{A Description of the Nature of Consultation and Collaboration}

School consultation is "a voluntary, non-supervisory relationship between professionals from differing fields established to aid one in his or her professional functioning" (Conoley \& Conoley, 1982, p.1) for the purpose of making a positive change in student behavior. This can be produced indirectly by engaging with teachers in collaborative problem solving (Kratochwill \& Van Someren, 1985). It is an ongoing, collaborative process through which students' needs are identified and appropriate strategies are implemented, monitored, and evaluated (Zins, Curtis, Graden, \& Ponti, 1988).

Traditionally, consultants have not provided direct services to students; but, Meyers, Parsons, and Martin (1979) included direct service as one of the four roles in which the consultant may serve. The gifted education consultant may provide direct services by working in a classroom to model certain practices and to collect information (e.g. assessment data) that can later be discussed with the teacher and to offer students differentiated services that they are qualified to deliver. Apart from having a positive impact on a student, a presumed outcome of consultation is that the teacher's knowledge, skills, and behavior will change to such a degree that consultation is less likely to be needed in the future when the teacher encounters a similar classroom situation. A consultant's job is not an easy one, especially since teachers rarely receive pre-service (or in-service) training on how to be a consultant (Haight, 1984). There are definite problems with teacher resistance to sharing responsibility for students they consider their own (Friend \& Bauwens, 1988). There is the possibility that teachers will see the use of a consultant as a sign of incompetence, which threatens their pride in teaching proficiency because the primary reasons for consultation are teachers' lack of knowledge, skills, and confidence in their ability to educate a student (Gutkin, 1981). There are also the usual problems in convincing teachers to do something that involves a change in attitude or procedure. It can be disconcert- ing and frustrating to consultants if teachers appear to agree to collaborate but do not actually do so, either passively avoiding a consultant, delaying implementation of suggested techniques, or actively denigrating the competence of the consultant to others.

\section{Collaborative os. Expert Consultation}

In providing consultative service, the consultant may act more or less as an expert or a collaborator in the relationship with teachers. When adopting the expert role (Tyler, Pargament, \& Gatz, 1983), the consultant acts as an authority who has responsibility for students in the teacher's class, and dispenses knowledge to which the teachers do not have access. Personal involvement may be minimal on the part of the consultant who accepts the expert role. Once a solution or answer is given to one teacher, the consultant would advance to the next problem situation and start all over. For this reason, the consultant is seen as an external force, even if he or she is a regular member of the school, since interactions with teachers are transient and episodic, lasting only as long as a teacher has a pressing concern. If a teacher does not request the consultant's assistance, it is unlikely that any substantive interaction will occur. However, it is also important that the teachers be given enough background information to be able to ask for assistance from the expert.

The consultant who operates more as a collaborator with teachers than as an expert attempts to take a shared approach to problem solving that results in shared responsibility for gifted learners. Zins, Curtis, Graden, and Ponti (1988), defined consultation as a collaborative problem-solving process, expressing the view that collaboration is at the core of the consultative relationship. According to Ward and Landrum (1994) it is a "misconception" only to consider consultation an expert-oriented model. The collaborative consultant takes an approach that is more process-oriented than outcome-oriented. The collaborative problem-solving process is utilized among two or more individuals through a sharing of expertise with the ultimate goals of better serving gifted learners for whom they bear some level of responsibility. When conducted in school, these efforts are called resource consultation.

The expectation in resource collaboration is that both parties are equal in status, are engaged in shared decision making, and are working toward a common goal (Friend \& Cook, 1990). Also, since collaboration should be perceived as voluntary, allowing the teacher to choose what strategies to implement, treatment integrity (Gresham, 1989), which refers to the degree 
to which an intervention is implemented as planned, should be higher than when a consultant acts as an expert suggesting a treatment. Research supports the conclusion that teachers tend to prefer service offered by a person taking a collaborative rather than an expert stance (Stewart, 1986).

\section{Factors in Consultation Effectiveness}

West and Cannon (1988) listed 47 competencies as being more or less important for collaborative consultants. The 10 individual competencies attaining the highest panel ratings indicated a consistent emphasis on interactive communication and problem-solving skills in the consultation process. Gresham and Kendell (1987) reviewed the research on consultation directed at teachers having difficulty educating students, and they made recommendations regarding the consultative process. Some of their suggestions may be applied to gifted education:

1. Speaking to teachers in behavioral terms rather than counseling terms is more likely to be effective in raising their expectation that they can successfully teach the student being discussed (e.g., noting that students learn faster than others their age, and, therefore, require a rapid pace of instruction and less practice).

2. Teachers prefer "common-sense" language over educational jargon when having an intervention described to them (e.g., showing them techniques like compacting rather than focusing on the concept of diagnostic-prescriptive teaching).

3. Teachers are more likely to identify resources they can use in carrying out an intervention plan if the consultant asks rather than tells them how to do it (e.g., resource teachers asking classroom teachers what "else" they would teach to extend particular learning experiences if they had the opportunity to do so).

4. Communication skills defined as genuineness, empathy, active listening, and paraphrasing have a significant impact on overall effectiveness of the consultant.

Good communication skills in building rapport are more important than providing "entry" information at the beginning of the consultative process (Martens, Lewandowski, \& Houk, 1989). Gutkin (1986) stated that the two most important consultant factors that affected teacher perception of consultation outcome were the consultant's knowledge and ability to make suggestions regarding the classroom situation and his or her overall communication skills. He also found that teachers have a pervasive preference to be actively involved during consultation interactions. It is important that the teacher incorporate some personally developed ideas into the intervention and that the consultation plan be detailed in writing. Gresham and Kendell (1987) found that teachers are most likely to follow through on an intervention plan developed through consultation if they are given instances in which the plan has worked in the past. Preferably, the plan has been implemented in the same school and the teacher(s) who have used the intervention are available to attest to its effectiveness (as well as the effectiveness of the consultant).

\section{Addressing Consultee Variables}

According to research cited by Gresham and Kendell (1987), the most frequently cited reasons given by teachers for not attempting a consultation plan are that they do not have the time and it is not fair or convenient to do something for just one child. It may be helpful if the consultant demonstrates effective intervention efforts in order to convince teachers of eventual benefits. Further, flexible grouping practices should be used among general education classrooms so that the intervention is ultimately being used more efficiently or effectively.

Friend and Bauwens (1988) offered some suggestions on how to reduce teacher resistance to consultation, including:

- learning the values of teachers (e.g., understanding how the needs of gifted learners rest among other demands, expectations, and priorities of individual teachers);

- gathering data on the effectiveness of consultative interventions (e.g., keeping a consulting log to record successes);

- establishing a mechanism for exchanging nonjudgmental feedback (e.g., focusing on changes in student behavior or the specific student objectives); and

- developing the consultation slowly and systematically with resistant teachers (e.g., letting the success with more cooperative teachers illustrate the effectiveness and benefits of the partnership).

Teachers tend to make more consultative contacts with consultants who are enthusiastic, but this may not be related to how well the interventions are implemented or their degree of success (Gutkin, 1986).

The consultant needs to take into consideration a teacher's professional knowledge, skills, teaching strategies, and personality (Hawryluk \& Smallwood, 1986). Difficulties in meeting student needs are often based on 
insufficient knowledge of theory, research, policy, or technique. A teacher may not be familiar with the characteristics of students targeted for intervention, instructional methods that are usually effective with them, nor what materials and resources in the school and community are available. Recent research (Archambault et al., 1993; Westberg, Archambault, Dobyns, \& Salvin, 1993) illustrates the lack of consistent use of appropriate instructional and curricular practices for gifted learners in elementary classrooms across the United States. Research also notes that a lack of appropriate teacher training in the area most likely accounts for the absence of appropriate differentiation.

Even when teachers possess the knowledge necessary for working with a particular group of students, they may lack either the skill, temperament, or the desire to do it. If teachers are convinced by the consultant that certain instructional techniques are always effective, but are then unable to implement them successfully, they may avoid any further consultation interactions. The consultant has to decide when and how much in-service training is necessary before asking teachers to implement instructional techniques or curriculum modifications that are new for them. Collaborative teaching allows consultant and consultee to work together until the consultee is confident and capable of developing and implementing differentiated lessons alone, over time, with systematic training opportunities. When the consultant plans a methodical movement from indirect to more direct services for gifted learners, there are allowances for the consultee to develop instructional and curricular competencies slowly (Dettmer \& Landrum, 1998). For example, a consultant might first develop a learning center for the classroom and, at a later date, just provide the classroom teacher with ideas for another enrichment center in the classroom.

\section{Barriers to Developing the Consultation Program}

There are several obstacles to creating an effective consultation program. They include personality conflicts or philosophical differences between consultant and teacher, general teacher resistance to change (Friend \& Bauwens, 1988), organizational variables under the control of administrators who are not supportive of consultation (Gutkin, Clark, \& Ajchenbaum, 1985), and poor communication skills on the part of the consultant (Safran, 1991). After a review of the literature on special education teacher consultants,
Haight (1984) concluded that the role is nearly impossible to handle because of insufficient role definition, increased demands on regular classroom teachers, lack of consideration for multiple responsibilities, inadequate support, and lack of professional preparation. In general, the implementation of a consultation program requires a change in teacher attitudes, knowledge, and skills at the classroom level, and a change in philosophy and allocation of (gifted) educational services at the system (i.e., school) level (Piersel \& Gutkin, 1983).

The most difficult situation for a consultant is when the school principal has established an atmosphere that inhibits teacher initiative and lesson planning that goes beyond traditional instruction of the prescribed curriculum. Gutkin, Clark, and Ajchenbaum (1985) compared the experience of two consultants working in different schools. In one school, the principal had developed an "open climate" in which there was open communication among staff and a generally supportive atmosphere. In the school with the open climate, the principal allowed the consultant to work freely with the teachers and allowed all staff the discretion to make their own decisions regarding planned interventions. The consultant who worked in a school with a closed climate spent most of his time helping teachers resolve their frustration over administrative policies and distrust of each other. The principal in this school was quite authoritarian; he had to approve every consultation plan, and he required teacher involvement in the consultation process. Their research showed that an open-climate school is more receptive to consultation services than a school with a closed climate. Administrators must be able to demonstrate three essential mechanisms for consultation program maintenance-advocacy, credibility, and support.

\section{Effective School Consultation}

After examining the evolution of school consultation since its emergence in the 1950s, Dettmer, Thurston, and Dyck (1993) defined the role of the school consultant today as

\footnotetext{
a facilitator of communication, cooperation, and coordination who consults, collaborates, and engages in teamwork with other educators to identify learning and behavioral needs, and plan, implement, evaluate educational programs to meet those needs. (p. 14)
}

The roles of consultant and consultee are not included in most traditional educational personnel preparation programs. This is a rethinking of the traditional roles of general education and personnel support staff. It will be important to educate resource consultation participants 
and to acknowledge the change in roles and expectations to the parents of gifted, talented, and creative students and school administrators. Landrum (1994) demonstrated improved teacher attitudes and comfort in participation in these roles with limited participation in in-service training. Havelock (1973) suggested that, as change agents, consultants may be in a number of different roles and will need to modify their approaches accordingly. As they serve in the roles of catalyst, solution giver, resource linker, or process helper, they may be asked to promote, inform, demonstrate, train, help, or nurture change in others. What is particular to consultants for the gifted is that they often have to proceed without jurisdiction. Neither the law nor school policy may require or value educational opportunities for gifted, talented, and creative students.

Classroom teachers may be nonbelievers or ambivalent in their beliefs about what constitutes appropriate education for gifted, talented, and creative students. Some teachers may believe that gifted, talented, and creative students must do all the work expected of others before providing any alternative. They may believe it is the role of students who have mastered grade-level materials to use their time to help other children who have not; or, they may believe grade-level instruction is sufficient no matter what the child may be ready to engage. Some teachers may not believe they are responsible for educating certain groups of students, such as gifted, talented, and creative students, particularly if their values and philosophical beliefs are not compatible with modifying the educational program for those students. The students may also make them uncomfortable because of their past experiences or personality characteristics. The consultant needs to assess such teacher variables before making his or her recommendations. A capacity for good teaching, therefore, is not enough; consultees have to want to use the skills demonstrated by the consultant, thus the volunteer nature of good consulting.

Consultants for gifted students must also develop support bases, not only within the classroom, but with the school administration and the broader community. They must be committed to building systems that will enhance the total school community. In such situations, they are clearly taking leadership roles (Gardner, 1988).

Parents and staff may perceive that a change in student service delivery is taking away from the quality of existing programs. Criticisms of resource consultation and collaboration may include misperceptions about the quality and quantity of services provided to gifted, talented, and creative students. However, research of service delivery in gifted education has indicated increased service to gifted learners in an effective consultation program (Landrum, 1994). It is important, then, to demonstrate how resource consultation can improve the frequency and diversity of student services. Further, it is important to demonstrate that, although some student services will be provided in the general education classroom, absolutely no "wateringdown" of services has to occur.

Unfortunately, most school climates are not conducive to collegiality and collaboration among staff members, much less school programs and the family. It is essential to address the needs for shared planning, mutual scheduling of teachers' classes, and other scheduling issues when implementing resource consultation and collaboration. The notion of shared decision making and shared responsibility must be respected and promoted. Although many school districts are attempting to make decisions collaboratively, this is not typical of traditional school settings.

\section{Benefits of the Consultation Model}

Caution is warranted in initiating resource consultation programs in gifted education, even though there are many advantages to the use of resource consultation and collaboration as a means for offering differentiated education and related student services to gifted, talented, and creative students. These advantages include enhanced and more efficient delivery of service to students in the context of improving the overall school system.

Consultation provides many enhancements to student service delivery. Increased student services and the enhanced diversity of services is evident through collaboration. Whereas gifted education services and general education opportunities afforded students are typically unrelated, resource consultation promotes the integration of services for a more comprehensive provision of student services. Certainly, improved teacher attitudes must also facilitate the education of gifted, talented, and creative students. Mutual responsibility and decision making for gifted student services are also promoted through collaboration. A professional network is supported for improved communication and evaluation of student services as well. Enhancements to the entire school system are possible when resource consultation and collaboration are initiated. Not only are gifted, talented, and creative students served more frequently, but other students not traditionally served by specialized programs in gifted education are also included. When the collaborative efforts in gifted education "spill over" to the school's 
population of nongifted students, gifted students are able to receive enrichment in the general education classroom, teacher instructional competence improves, and the use of innovative instructional strategies in the regular classroom increases. The change in general educators' involvement in the education of the gifted is an opportunity for regular teachers to expand their more limited role of simply referring students for services.

Resource consultation can be an efficient and costeffective service delivery model. This approach makes minimal use of consumable resources by pooling the collective expertise of all school personnel. A model that uses a hierarchical collaboration makes the best use of the school staff's time.

We can learn much from the collaborative models used by special education. However, gifted education collaboration is unique in that the consultants must be able to work effectively with multiple constituencies whose concerns must be necessarily addressed. Some of these are in common with other special need populations, some of these are challenges that arise only for those working to implement change on behalf of gifted, talented, and creative students. Although the use of collaboration for gifted education has been minimal, it is very viable (Robinson \& Ringlaben, 1992). Recommendations for such efforts have been made by experts in the area of resource consultation (Dettmer, 1989; Dettmer \& Lane, 1989; Dyck \& Dettmer, 1989; Idol-Maestas \& Celentano, 1986).

Research on general education teachers' classroom practices includes observations indicating limited provisions for gifted learners and anecdotal records of teachers requesting more assistance in providing challenging learning experiences to gifted learners (Westberg, Archambault, Dobyns, \& Salvin, 1993). Classroom teachers also want better access to consultants for gifted education, especially assistance in locating appropriate enrichment materials (Renzulli \& Reis, 1994). Other studies have indicated a call for a shift of roles of gifted teachers and more differentiated services in the general education classroom (Archambault et al., 1993), conditions that are conducive to collaboration and consultation.

\section{A Resource Consultation Model in Gifted Education}

One specific resource consultation model evaluated in the area of gifted education was developed originally by Curtis, Curtis, and Graden (1988) and adapted for gifted education (Ward \& Landrum, 1994). This model conceptualizes the collaborative process for schools in which consultation represents a problem-solving process shared by all school personnel. A primary goal of this model is to use limited and expensive resources more effectively and efficiently to better serve students. In times of economic hardships in particular, almost any services and materials given to gifted, talented, and creative students are limited and perceived to be extravagant.

According to the Ward and Landrum model, consultation for student-related problems can occur at different levels. This model allows for the filtering of cases at each level of the hierarchy. At Level One, teachers seek to collaborate with other teachers on a less structured and informal basis. In many instances, this type of collaboration, which allows for joint exploration of the problem and sharing of ideas for intervention, will result in successful resolution. Consequently, there is no need for outside assistance from resource personnel. Classroom teachers seek assistance from specialized gifted education personnel at Level Two of the model. This typically occurs when efforts at Level One have proven unsuccessful. For example, classroom teachers may consult the gifted education resource teachers for assistance in making instructional changes or locating necessary resources for differentiated education. Level Three represents team intervention whereby several staff members are affected by the decision making, such as that needed for comprehensive student assessment or for making provisions regarding course or grade acceleration.

Research (Landrum, 1994) has shown that most (85\%) of the time, the gifted resource specialist is engaged in Level Two consultation. Typically, this includes giving demonstration lessons in classrooms to illustrate instructional strategies, lesson development with teachers, and team teaching in the regular classroom. Ten percent of his or her time is spent in Level One activities that involve resource collection and providing information or materials upon request. Five percent of his or her time is devoted to Level Three activities involving parent conferences or student identification meetings. There is a steady increase over time in the amount of gifted education services provided not only to gifted, talented, and creative students, but also to students not identified as gifted. Enrichment activities are made available to students who would otherwise not have been involved in gifted education services. Further, a focus on the nature of consulting activities among general education and 
gifted education teachers has produced data that describe the practical application of the model in developing and implementing differentiated educational services for gifted, talented, and creative students. These findings have important implications for future implementation of such models and related staff training in this area. The demonstration lessons conducted in the study, for example, were seen as opportunities both to show teachers how to engage students in higher order thinking and creative thinking and also to offer direct services to students and help teachers to recognize what Renzulli (1986) called "gifted behaviors." Teachers had the opportunity to witness the demonstration of highly intelligent and creative responses from students whom they may not have considered gifted, talented, or creative. This is important in identifying students who could benefit from involvement in more demanding enrichment activities than are usually given in the classroom.

In summary, resource consultation has been demonstrated to be effective in the provision of differentiated education to gifted, talented, and creative students (Landrum, 1994). The educational services provided to gifted students were made accessible to unidentified students. The improved quality of student products for both identified and unidentified students supports the educational benefits of this approach. Overall, the school system was enhanced by resource consultation, rather than just those services provided to gifted, talented, and creative students. With the use of resource consultation, there was a steady increase over time of the amount of services provided to all students. Most importantly, the study of the nature of resource consultation efforts raised issues key to further implementations of efforts and questions for future research.

\section{Directions for Future Research}

Foremost, resource consultation research in gifted education should strive to duplicate results found in similar studies in related fields. For example, resource consultation applied to special education has led to time (Curtis, Curtis, \& Graden, 1988) and cost efficiency (Knoff, \& Batsche, 1991), improvement in student and teacher behaviors and expanded roles for the school system (Graden, Casy, \& Bonstom, 1985), high expectations from teachers (Curtis \& Meyers, 1985), positive teacher attitudes (Kratochwill \& Van Someren, 1985), and enhancement of student social and academic success (Idol, 1989; Jason \& Perone, 1978; Knoff \& Batsche, 1991; Rosenfield, 1992). In general, the research base on consultation consists of studies of the consultative process, staff development, effectiveness of models, teacher competencies, and proficiency of consultees (Dettmer, Thurston, \& Dyck, 1993). They advocate similar research in gifted education.

Directions for future research for resource consultation include all aspects of the consultation process. For example, there is a need to study individual consultation plans themselves. Gresham and Kendell (1987) called for the study of the integrity of the consultation plan, while Clark and Peterson (1986) pointed to the study of translation of principles of practice into action or professionalism as it relates to consultation. Other directions include Cancelli and Lange's (1990) concerns for studying the institutionalization of consultation in schools. And Rosenfield (1992) called for ongoing research into the consultation process by studying each phase of the process. The specific need for studying consultation outcomes is also recommended (Witt, Erchul, McKee, Pardue, \& Wickstom, 1991). The importance of staff development in the consultation process has been demonstrated many times (Idol, 1989; Pritchard \& Marshall, 1994; Stringer, Strow, Hibbert, Powell, \& Louw, 1992). Therefore, future research in consultation should continue to study requisite staff development and the nature of those experiences. Researchers have called for more rigorous consultation in future studies (West \& Idol, 1987) because previous methodology has not been rigorous (Gresham \& Kendell, 1987). West and Idol also called for the use of more technically adequate instrumentation. Rosenfield (1992) pointed to the need for a variety of research methodologies in future research of school-based consultation.

The replication of the limited existing research in the area of gifted education also is a priority in future empirical efforts. Given the inconsistent or diverse nature of educational practices for gifted, talented, and creative students across sites, a variety of institutional contexts using resource consultation and collaboration must be compared and contrasted. Empirical evidence of improved student academic performance and desirable changes in teacher competence must be collected. This information is necessary to sell resource consultation to educators, administrators, and parents. It is important to develop research regarding the educational staff's receptivity of expanding its role in gifted education and the appropriate selection of those individuals who will become initially involved in collaboration and consultation. This information has important implications for the hiring, training, and evaluation of 
school staff responsible for collaboration activities for gifted, talented, and creative students.

\section{Summary and Conclusions}

From a review of the literature on consultation effectiveness, it seems that in the ideal consultative relationship the consultant is viewed as an expert in the area in which the teacher is seeking assistance, is familiar to the teacher, is readily accessible, establishes an easy rapport, and is able to communicate effectively. The consultant then guides the teacher through a process of problem solving and shared decision making that culminates in meeting mutually satisfactory goals.

The teacher in the consultative relationship voluntarily invites consultation, is receptive to suggestions, has in-depth understanding of the nature and needs of his or her students, understands the district's goals as they apply to gifted, talented, and creative students, and is skillful and persistent in pursuing these goals. It is crucial that both consultant and teacher engage the consultative process with mutual respect and a shared commitment to enhancing the educational opportunities for gifted, talented, and creative students. Since each member of the consultation team has expertise to contribute, the relationship should be viewed as mutually beneficial.

The transition from being a teacher of the gifted to being a consultant requires training and support. Perhaps the major obstacle confronting the consultant is establishing expertise while simultaneously leading teachers to see that expertise as a resource rather than a threat or criticism. Other potential obstacles include convincing teachers to try new ideas and helping them acquire new knowledge and skills.

The teachers of the gifted must make some significant transitions when they become consultants. They must view the development of others' skills in meeting the learning needs of gifted, talented, and creative students as professionally gratifying as when they performed these tasks themselves. To ease this transition, as well as to ensure that consultants maintain their professional credibility with teachers, the enrichment specialist should continue to provide, whenever possible, both direct and indirect services to gifted, talented, and creative students.

As teachers and enrichment specialists learn to collaborate more effectively and consistently, they will forge many new identification and talent development initiatives that could enhance our ability to identify talent in students who are currently underrepresented in enrichment programs. Renzulli (1994) suggested that, through the consultative process, information can be used by the enrichment specialist to make informed decisions about talent development in the regular classroom, the formation of talent clusters, and the expansion of the special services offered to students. Success in this endeavor will enhance the classroom teacher's ability and the enrichment specialist's knowledge base so that together they can better meet the complex and challenging educational needs of gifted, talented, and creative students.

\section{References}

Archambault, F. X., Westberg, K. L., Brown, S., Hallmark, B. W., Zhang, W., \& Emmons, C. L. (1993). Classroom practices used with gifted third and fourth grade students. Journal for the Education of the Gifted, 16, 103-119.

Cancelli, A. A., \& Lange, S. M. (1990). Considerations for future research in the institutionalization of school-based consultation. Journal of Educational and Psychological Consultation, 1, 87-98.

Clark, C. M., \& Peterson, P. L. (1986). Teacher's thought process. In M. C. Wittrock (Ed.), Third handbook on research on teaching (pp. 255-314). New York: Macmillan.

Conoley, J. C., \& Conoley, G. W. (1982). School consultation: A guide to practice and training. New York: Pergamon.

Curtis, M. J., Curtis, V. A., \& Graden, J. L. (1988). Prevention and early intervention assistance programs. School Psychology International, 9, 257-264.

Curtis, M. J. \& Meyers, J. (1985). Best practices in school-based consultation. In A. Thomas \& J. Grimes (Eds.), Best practices in school psychology. Washington, DC: National Association of School Psychologists.

Dettmer, P. (1989). The consulting teacher in programs for gifted and talented students. Arkansas Gifted Education Magazine, 3(2), 4-7.

Dettmer, P., \& Landrum, M. S. (1998). Staff development: The key to effective gifted education. Waco, TX: Prufrock Press.

Dettmer, P., \& Lane, J. (1989). An integrative model for educating very able students in rural school districts. Educational Considerations, 17(1), 36-39.

Dettmer, P., Thurston, L., \& Dyck, N. (1993). Consultation, collaboration, and teamwork for students with special needs. Boston: Allyn Bacon.

Dyck, N., \& Dettmer, P. (1989). Collaborative consultation: A promising tool for serving gifted students with learning disabilities. Reading, Writing, and Learning Disabilities, 5, 253-264.

Friend, M., \& Bauwens, J. (1988). Managing resistance: An essential consulting skill for learning disabilities teachers. Journal of Learning Disabilities, 2, 556-561.

Friend, M., \& Cook, L. (1990). Collaboration as a predictor for success in school reform. Journal of Educational and Psychological Consultation, 1, 69-86.

Gardner, J. (1988). Leadership: An overview. Leadership papers/12 Leadership Studies Program. Washington, DC: Independent Sector.

Graden, J. L., Casey, A., \& Bonstrom, O. (1985). Implementing a prereferral intervention system: Part II. Exceptional Children, 51, $487-496$ 
Gresham, F.M. (1989). Assessment of treatment integrity in school consultation and preferred intervention. School Psychology Review, 18, 37-50

Gresham, F. M., \& Kendell, G. K. (1987). School consultation research: Methodological critique and future research directions. School Psychology Review, 18, 37-50.

Gutkin, T. B. (1981). Relative frequency of teacher lack of knowledge, skills, confidence, and objectivity in school settings. Journal of School Psychology, 19, 57-61.

Gutkin, T. B. (1986). Consultees' perceptions of variables relating to the outcomes of school-based consultation interactions. School Psychology Review, 15, 375-382.

Gutkin, T. B., Clark, J. H., \& Ajchenbaum, M. (1985). Impact of organizational variables on the delivery of school-based consultation services: A comparative case study approach. School Psychology Review, 14, 230-235.

Haight, S. L. (1984). Special education teacher consultant: Idealism versus realism. Exceptional Children, 50, 507-515.

Havelock, R. (1973). The change agent's guide to innovation in education. Englewood Cliffs, NJ: Educational Technology Publications.

Hawryluk, M. K., \& Smallwood, D. L. (1986). Assessing and addressing consultee variables in school-based behavioral consultation. School Psychology Review, 15, 519-28.

Idol, L. (1989). The resource/consulting teacher: An integrated model of service delivery. Remedial and Special Education, 10(6), 38-48.

Idol-Maestas, L., \& Celentano, R. (1986). Teacher consultant services for advanced students. Roeper Review, 9(1), 34-36.

Jason, L. A., \& Perone, L. (1978). Evaluating, ecological, behavioral, and process consultation interventions. Journal of School Psychology, 17, 103-115.

Knoff, H. M., \& Batsche, G. M. (1991). Guiding school-based organizational change using university-based preservice training. Paper presented at the annual meeting of the National Association of School Psychologists, Dallas, TX

Kratochwill, T. R., \& Van Someren, K. R. (1985). Barriers to treatment success in behavioral consultation: Current limitations and future directions. Journal of School Psychology, 23, 225-239.

Landrum, M. (1994, April). Study of the nature of effective resource consultation in the education of the gifted. Paper presented at the annual meeting of the American Educational Research Association, New Orleans, LA.

Martens, B. K., Lewandowski, L. J., \& Houk, J. L. (1989). The effects of entry information on the consultation process. School Psychology Review, 18, 225-234.

Meyers, J., Parsons, R., \& Martin, R. (1979). Mental health consultation in the schools. San Francisco: Jossey-Bass.

Parke, B. N. (1989). Gifted students in the regular classroom Boston: Allyn Bacon.

Piersel, W. C., \& Gutkin, T. B. (1983). Resistance to school-based consultation: A behavioral analysis of the problem. Psychology in the Schools, 20, 311-320.
Pritchard, R. J., \& Marshall, J. C. (1994). Evaluation of a tiered model for staff development and writing. Research in the Teaching of English, 28, 259-285.

Renzulli, J. S. (1986). The three ring conception of giftedness: A developmental model for creative productivity. In R. J. Sternberg \& J. E. Davidson (Eds.), Conceptions of giftedness (pp. 53-92). New York: Cambridge University Press.

Renzulli, J. S. (1994). Schools for talent development: A practical plan for total school involvement. Mansfield Center, CT: Creative Learning Press.

Renzulli, J.S., \& Reis, S. M. (1991). The reform movement and the quiet crisis in gifted education. Gifted Child Quarterly, 35 26-35.

Robinson, A., \& Ringlaben, R. (1992). Ideas with impact: Consultant teacher. Journal for the Education of the Gifted, 16, 83-87.

Rosenfield, S. (1992). Developing school-based consultation teams: A design for organizational change. School Psychology Quarterly, 1(1), 27-46.

Safran, J. S. (1991). Communication in collaboration/consultation: Effective practices in schools. Journal of Educational and Psychological Consultation, 2, 371-386.

Stewart, K. J. (1986). Innovative practices of indirect service delivery: Realities and idealities. Psychology Review, 15, 466-478.

Stringer, P., Stow, L., Hibbert, K., Powell, J. \& Louw, E. (1992). Establishing staff consultation groups in schools: A programme to train facilitators of school based staff support groups in consultancy. Educational Psychology in Practice, 8(2), 87-96.

Tomlinson, C. A. (1994/1995). Response: Gifted learners too: A possible dream. Educational Leadership, 52(4), 68-69.

Tyler, F. B., Pargament, K. I., \& Gatz, M. (1983, April). The resource collaborator role: A model for interactions involving psychologists. American Psychologist, 388-398.

Ward, S. B., \& Landrum, M. S. (1994). Resource consultation: An alternative service delivery model for gifted education. Roeper Review, 16, 276-279.

West, J. F., \& Cannon, G. S. (1988). Essential collaborative consultation competencies for regular and special educators. Journal of Learning Disabilities, 21, 56-63.

West, J. F., \& Idol, L. (1987) School consultation (Part I): An interdisciplinary perspective on theory, models, and research. Journa of Learning Disabilities, 20, 385-408.

Westberg, K. L, Archambault, F. X., Dobyns, S. M., \& Salvin, T. J. (1993). The classroom practices observation study. Journal for the Education of the Gifted, 16, 120-146.

Witt, J. G., Erchul, W. P., McKee, W. T., Pardue, M., \& Wickstom, K. F. (1991). Conversational control in school-based consultation: The relationship between consultant and consultee topic determination and consultation outcome. Journal of Educational and Psychological Consultation, 2, 101-116.

Zins, J., Gurtis, M., Graden, J., \& Ponti, C. (1988). Helping students succeed in the regular classroom. San Francisco: Jossey-Bass. 